\title{
The Effects of Perspective-Taking on Prosocial Behavior in Early Childhood
}

\author{
Rizky Drupadi ${ }^{1, *}$ Yulia Ayriza ${ }^{2}$
}

\author{
${ }^{1}$ Early Childhood Education Department, Lampung University, Bandar Lampung, Indonesia \\ ${ }^{2}$ Psychology Department, Yogyakarta State University, Yogyakarta, Indonesia \\ *Corresponding author. Email: rizky.drupadi@fkip.unila.ac.id
}

\begin{abstract}
This study aimed to investigate the influence of perspective-taking on prosocial behavior in early childhood. The research used quantitative approach with the ex post facto design used survey data collection. The sample of this research was taken by using a stratified proportional random sampling technique. The samples were 300 children in Sleman, Yogyakarta. The data obtained through a questionnaire given to teachers to obtain perspective-taking data on children and used interviews to obtain the children's data prosocial behavior. The data were analysed by a linear regression analysis. The result showed that there was an effect of perspectivetaking on prosocial behavior in early childhood $(\mathrm{p}<0.05)$. It means that perspective-taking could predict prosocial behavior in early childhood.
\end{abstract}

Keywords: Perspective-taking, prosocial, early childhood

\section{INTRODUCTION}

Early childhood is an individual aged 0 to 6 years old who experiences a development process, includes characters and personality establishment, rapidly and fundamentally (Sujiono, 2011). At this time, children should be stimulated to develop several aspects such as religion, moral, physical, language, cognitive, emotional, social, and art aspects. It is supported by brain's development of young children that can develop up to $80 \%$ of the adult's brain (Suyadi, 2010). Therefore, education should be conducted in early childhood to generate better generations in the future.

One important aspect in term of early childhood development is social-emotional. The aspect of prosocial behavior is a basic part of the achievement level of emotional social development. Eisenberg and Mussen explained that prosocial behavior is voluntary action intended to help or benefit others or groups of people (Eisenberg \& Mussen, 1989). This prosocial behavior includes sharing something with others, showing willingness to work together, helping and entertaining someone in distress. This prosocial behavior plays an important role in social life. If human cannot show prosocial behavior such as helping, sharing, and working together, it will be difficult to live in the social groups. Basically, humans are social creatures, who need a help of others in their lives.

It is not only experienced and felt by adults but also for children as well. Children are not adult miniature. They have unique personalities whose existence must be recognized. Besides, they are part of the family, a group of relatives, the neighborhood environment, society, country, and the world. To become a member of the environment of life from the beginning, the children need to learn the rules in social life from the beginning, especially prosocial behavior.

The development of prosocial behavior is an important type of social competence possessed by early childhood. This early development would be a further determinant. Marion said that prosocial behavior was intended to meet a person's needs, whether physical, psychological/emotional, or both (Marion, 2015). In line with Eisenberg, prosocial behavior was stable from early childhood to early adulthood (Santrock, 2007). Therefore, prosocial behavior must be instilled into early children in learning through Early Childhood Education (ECE) regarding readiness to go up to primary school. The facts on prosocial behavior show different things. Verbal aggressiveness still often occurs; shown by the presence of children, who say bad things to friends, seize belongings from friends, hit friends and others. Besides psychological aggression such as not allowing friends to join into play, not allowing friends to sit nearby also often happens. It is quite concerned, considering it happens in early childhood.

In digital era, the access of social media such as television could give a negative effect for children. Friedrich and Stein found that aggressive behavior and prosocial behavior of television programs influenced the behavior of early childhood, both negative and positive effects (Friedrich \& Stein, 1973). Yet, in line with Dumova's research, television has a positive effect on children by exploring prosocial themes and developing communityoriented content (Dumova, 2006). In Indonesia, the social media tend to display uneducated content such as violence which is easy for children to imitate. Several observations through interviews conducted to kindergartens' teachers obtained to find out the prosocial behavior, yet some of them were not feasible. Prosocial behavior can be seen when child approached his friend who cried, then some 
children who share their lunch with his friend or play with his friends. Meanwhile, there are also children's behavior such as fighting over toys, crying, ignoring other children, playing independently since they do not feel connected each other. In addition, prosocial behavior will affect the development of child interaction with peers. Battistich argues that prosocial behavior influences the social adjustment of children in the school (Battistich, 2003). In general, children, who are able to socialize, will easily receive positive reactions from peers when showing prosocial actions (Eisenberg \& Mussen, 1989).

Through observations in kindergarten, prosocial behavior was rarely encountered. It can be seen from their behaviors such as disturbing friends while learning, hitting friends, mocking friends by saying "cengeng"or mushy, do not want to share lunch and toys, and giggling to friend who felt down rather than help him and so on. Those behaviors often distract the learning process in the classroom. Furthermore, if this behavior runs all the time, it will increase the psychological disturbance of children towards aggression among children. According to McDevitt and Ormrod, aggression is a deliberate action taken to hurt others both physically and psychologically (McDevitt \& Ormrod, 2014). Aggressive children tend to have problems in dealing with emotions and understanding social relationships. This is a strong indicator of low mental health when reaching adulthood later.

Development of prosocial aspects needs to be a major concern. Marion said that prosocial behavior was intended to meet a person's needs, whether physical, psychological/emotional, or both. It is very important to understand the mechanism of integration that occurs between cognitive and emotional processes in development, especially in prosocial behavior (Marion, 2015).

Vasta, Haith, and Miller's believed that perspective-taking is the basic explanation of cognitive development of prosocial behavior. In fact, the prosocial behavior of early childhood is low, even though the perspective-taking of the child has developed (Vasta, Haith, \& Miller, 1995). Moreover, perspective-taking is the ability to be able to put yourself in the position of others (Baron \& Byrne, 2003). It means understanding the thoughts and feelings of others by using the perspectives of others. Hinnant and Brien stated that there are two abilities in perspectivetaking which are cognitive and affective (Hinnant \& O'Brien, 2007). Cognitive perspective-taking is the ability to imagine how certain things experience from another person's point of view, while affective perspective-taking is the ability to understand other people's feelings by taking that person's point of view. Batson and Eisenberg explained that perspective-taking increases the ability of individuals to identify, to understand and to sympathize the needs of others (Damon, Lerner, \& Eisenberg, 2006).

Piaget said that children aged 2-7 years are included in the pre-operational stage (Santrock, 2007). At Piaget's preoperational stage, a child's cognitive abilities are characterized by an inability to use another person's perspective (egocentrism). Piaget used three-mountain assignments and assesses with the child's self-perspective, and the tendency of children to see themselves as a center of activity (Santrock, 2007). Children tend to feel that their perspective of the world is the only right one. As a result, children are less able to understand the thoughts and feelings of others that can be different from them.

Knowing the facts, free play activities often occur fighting for toys. One child with other children is fighting for toys that they like, without seeing that other people also want it. The child only knows that he or she really wants the toy and does not understand that other children want it too, so the result is selfish due to fighting for toys. Beaty stated that egocentric perspectives will change in line with cognitive maturity and experience, when a child can see things from the others perspective. It can be seen if children could show empathy and affection for the suffering of others (Beaty, 2013). Unlike Borke in his research, it concluded that young children are not always egocentric when thinking and acting (Salkind, 2004), meaning that Child's egocentric attitude is not related to age, for instance children can perform perceptual role (perceptual role-taking ability). For children, prosocial action proved when a child could make a difference between his perspective and others. Based on the background proposed, the researcher tried to examine the influence of the perspective-taking on prosocial behavior of young children. In detail, the problem of this study was "Is there an effect of perspective-taking on prosocial behavior?".

The purpose of this study was to determine the effect of perspective-taking on prosocial behavior of young children. The benefit obtained from this research was theoretically for the prosocial behavior development of of early childhood.

\section{METHOD}

The research used quantitative methods with ex post facto design with survey data collection. The population in this study was kindergarten in Sleman District, which amounted to 1017 children. The samples were 300 children. The sampling used stratified proportional random sampling technique. Also, teachers were involved into the interviews.

Data obtained through observations and interviews. Performance assessment will be carried out in taking an affective perspective adopting a measurement model from Kurdek and Rodgon (Kurdek \& Rodgon, 1975). The first task, measurement using a picture card. This performance assessment used four cards of facial expressions which were happy, sad, scared, and angry. It aimed to introduce various kinds of emotions. The second task was about responding a situation through discussion session about story given. The prosocial scale was developed based on the theory from Eisenberg that included four aspects namely sharing, cooperation, helping and entertaining. Assessment of children's prosocial behavior by asking questions directly to the child such as "If there are friends who invite you to play together. Are you going to play 
with him? or If you see your friend crying. Will you give your toys to cheer him up? "

The validity of the instrument used content validity whereas reliability test used the Cronbach's alpha formula that showed that the reliability of Perspective-Taking scale was 0.914 of 28 items while for prosocial behavior scale was 0.865 out of 22 items. Thus, the data have fulfilled the requirements of regression analysis, then linear regression analysis was employed.

Table 1 Results of regression analysis

\section{RESULT AND DISCUSSION}

The result showed there was an effect of perspectivetaking on prosocial behavior in children $(0.000<0.05)$. The results of the regression analysis can be seen in Table 1 .

\begin{tabular}{|c|c|c|c|c|c|}
\hline \multicolumn{6}{|c|}{ Coefficients } \\
\hline \multirow[b]{2}{*}{ Model } & \multicolumn{2}{|c|}{ Unstandardized Coefficients } & \multirow{2}{*}{$\begin{array}{c}\text { Standardized Coefficients } \\
\text { Beta }\end{array}$} & \multirow[b]{2}{*}{$\mathbf{t}$} & \multirow[b]{2}{*}{ Sig. } \\
\hline & B & Std.Error & & & \\
\hline Constant & 2.666 & 1.410 & & 1.891 & .060 \\
\hline $\begin{array}{l}\text { Perspectives } \\
\text { taking }\end{array}$ & .455 & .062 & .390 & 7.304 & .000 \\
\hline
\end{tabular}

Based on Table 1, the regression equation $\mathrm{Y}=2.666+$ $0.455 \mathrm{X}$ was obtained. Based on the equation, if the $\mathrm{X}$ value was known, the $\mathrm{Y}$ value can be determined by multiplying the $X$ value by the coefficient value $(0.455)$ which was then added to the constant value (2.666). It means that the more the value of $X$ increases, the more the value of $\mathrm{Y}$ increases, according to the direction of the regression coefficient, the regression coefficient was Table 2 Effective donations positive. Thus, it can be concluded that the increasing value of perspective-taking also increases the value of child prosocial behavior. Conversely, if the value of perspective taking decreases, the value of child prosocial behavior will decrease, then the equation can be used to predict.

The amount of effective contribution and relative perspective and regulation taking can be seen below.

\begin{tabular}{|l|l|l|l|l|}
\hline Model & \multicolumn{1}{|c|}{$\mathbf{R}$} & $\begin{array}{c}\text { R } \\
\text { Square }\end{array}$ & Adjusted R Square & Std. Error of the Estimate \\
\hline 1 & .390 & .152 & .149 & 3.09229 \\
\hline \multicolumn{2}{|l}{ Predictors: (Constant), Perspectives taking } \\
\hline
\end{tabular}

Table 2 shows the effective contribution ( $\mathrm{R}$ Square) perspective-taking was 0.152 or $(15.2 \%)$ on prosocial behavior of early childhood. Meanwhile, $84.8 \%$ of prosocial behavior of young children was influenced by other factors.

Based on hypothesis testing, it was proven that there was a positive and significant effect between perspective-taking on prosocial behavior of children. It means that perspective-taking can predict prosocial behavior of children aged 5-6 years. Additionally, the results of this study were supported by the research of Cigala, Mori, and Fangareggi who stated that children with better perspective-taking abilities tend to behave prosocial when doing a social interaction (Cigala, Mori, \& Fangareggi, 2015). Lupinetti mentioned specifically that there was a positive relationship between the ability to take affective perspectives and prosocial behavior (Gülay Ogelman, Oğuz, Körükçü \& Köksal Akyol, 2017). It also explained that if the perspective-taking ability of the child was good, it tended to behave prosocial well. It was in line with Selman, explained that perspective-taking in early childhood had developed at the age of 3 years (Kail \&
Cavanaugh, 2013). At Selman's level of perspectivetaking, of children aged 3-6 years were at level 0 (undifferentiated perspective-taking) and also aged 4-9 years were at level 1 (social-informational perspectivetaking).

In this study, researchers conducted research on children aged 4-6 years, which were at level 0 and 1 of Selman's levels of perspective-taking stages. At the undifferentiated level, children have already understood that they and others have different thoughts and feelings, although it is still often confusing. At the social-informational stage, children have already known that their perspectives are different from others and are able to explain their different views. Indirectly, it showed that children aged 4-6 years could take the point of view of themselves and others. Thus, children have already understood perspective-taking and selectively taken other people's perspectives in social interactions (Zhao, Malle, \& Gweon, 2016).

Therefore, it can be concluded that the development of perspective-taking in children was appropriate, especially affective perspective-taking on children. It also explained that perspective-taking on children was true that early 
childhood was not always egocentric when thinking and acting. Furthermore, Borke said that a prosocial action occurred when children could make a difference between their perspective and others (Salkind, 2004).

In the perspective-taking variable, there were factors that provide an appropriate emotional response in responding to a situation. Agree with Goleman who said that oneyear-old children display different behaviors depending on happiness, anger, and other emotions that are described by people around them (Goleman, 2004). Then, a three-yearold child is able to identify happy and sad faces and children aged 4 to 5 can identify happy, scared, angry, and sad faces. This study examined 4-6 years old children so that it can be concluded that the child has been able to provide an appropriate emotional response in responding to a situation.

Regarding the process of early childhood education, it was necessary to develop the ability to take-perspective in children. Together with Yusuf who stated that one aspect of social skills in the ability to build relationships with others in early childhood was the ability to accept other people's points of view (Mursid, 2016). This ability can be developed in the beginning with the model that children see, for instance a behavior that was shown by parents, siblings, relatives, shows on television, friends or people around the children. The next stage was a behavior imitation based on model they saw. Then, if the behavior did not get a response from the parents, it confirmed that the behavior would be internalized on them and became their characters (Mursid, 2016).

It was important to note, that the present evidence showed that perspective-taking had a positive effect on prosocial behavior, meaning that perspective-taking could predict the prosocial behavior of children.

\section{CONCLUSION}

The main conclusion that can be drawn was that perspective-taking had a positive effect on prosocial behavior of early childhood. It was positive that perspective-taking could predict prosocial behavior of early childhood. Perspective-taking contributed effectively on prosocial behavior.

To develop prosocial behavior, it could be done by increasing the perspective-taking of children and vice versa Therefore, children aged 4-6 years whose development of prosocial behavior was not optimal, the results of this study could be a reference in improving prosocial behavior of children, specifically those who aged 4-6 years.

\section{REFERENCES}

Baron, R. A. \& Byrne, D. (2003). Psikologi sosial. Jakarta: Erlangga.

Battistich, V. (2003). Effects of a school-based program that enhance prosocial development on children's peer relations and social adjustment. Journal of Research in Character Education, 1(1), 1-16.

Beaty, J. J. (2013). Observasi perkembangan anak usia dini. Jakarta: Kencana.

Cigala, A., Mori, A., \& Fangareggi, F. (2015). Learning others' point of view: Perspective taking and prosocial behaviour in preschoolers. Early Child Development and Care, 185(8), 1199-1215. doi:https://doi.org/10.1080/03004430.2014.987272

Damon, W., Lerner, R. M. \& Eisenberg, N. (2006). Handbook of child psychology 6 th edition. New Jersey: John Wiley \& Sons Inc.

Dumova, T. (2006). Prosocial learning. International Journal of Learning, 12(9), 184-194.

Eisenberg, N. \& Mussen, P. H. (1989). The Roots of prosocial behavior in children. Inggris: Cambridge University Press.

Friedrich, L. K., \& Stein, A. H. (1973). Aggressive and prosocial television programs and the natural behavior of preschool children. Monographs of the Society for Research in Child Development, 38(151), 1-64.

Goleman, D. (2004). Emotional intelligence. Jakarta: Gramedia Pustaka Tama.

Gülay Ogelman, H., Oğuz, V., Körükçü, Ö., \& Köksal Akyol, A. (2017). Examination of the effect of perspective-taking skills of six-year-old children on their social competences. Early Child Development and Care, 187(1), 59-67.

doi:https://doi.org/10.1080/03004430.2016.1150274

Hinnant, J. B., \& O'Brien, M. (2007). Cognitive and emotional control and perspective taking and their relations to empathy in 5-year-old children. The Journal of Genetic Psychology, 168(3), 301-322. doi:https://doi.org/10.3200/GNTP.168.3.301-322

Kail,R.V., \& Cavanaugh J. C. (2013). Human development a life-span view (sixth edition). Canada: Wadsworth.

Kurdek, L. A., \& Rodgon, M. M. (1975). Perceptual, cognitive, and affective perspective taking in kindergarten through sixth-grade children. Developmental Psychology, 11(5), 643.

Marion, M. (2015). Guidance of young children. USA: Pearson. 
McDevitt \& Ormrod. (2014). Child development and education. England: Pearson.

Mursid. (2016). Pengembangan pembelajaran PAUD Bandung: Remaja Rosda Karya.

Salkind, N. J. (2004). Teori-teori perkembangan manusia pengantar menuju pemahaman holistik (terjemahan M.Khozim). New Delhi: Sage Publication.

Santrock, J. W. (2007). Perkembangan anak. Jakarta:

Erlangga.

Sujiono, Y. N. (2011). Konsep dasar PAUD. Jakarta: Permata Puri Media.

Suyadi. (2010). Psikologi belajar pendidikan anak usia dini. Yogyakarta: Pustaka Insan Madani.

Vasta, R., Haith, M. M., \& Miller, S. A. (1995). Child psychology the modern science (second edition). USA: John wiley \& Sons, Inc.

Zhao, X., Malle, B. F., \& Gweon, H. (2016). Is it a nine, or a six? Prosocial and selective perspective taking in four-year-olds. In $\mathrm{CogSci}$. 